DAKWATUNA

Jurnal Dakwah dan Komunikasi Islam

Volume 6, Nomor 2, Agustus 2020

p-ISSN: 2443-0617

e-ISSN: 2686-1100

\title{
Post Dakwah di Era Cyber Culture
}

\author{
Harry Purwanto \\ Institut Agama Islam Syarifuddin Lumajang, Indonesia \\ Email: purwa4@gmail.com
}

\author{
Achmad Arifulin Nuha \\ Institut Agama Islam Syarifuddin Lumajang, Indonesia \\ Email: jtv1lumajang@gmail.com
}

\begin{abstract}
The development of technology has a big influence in all aspects of life, including in da'wah. Preachers face the challenges in the era of cyber culture, where information flow and cultural development are connected with the digital space. This article discusses the relationship between da'wah and cyber culture. Accompanied by any challenges that must be faced by preachers, as well as how the right strategy to convey Islamic teachings in the current era. In another section, also stated what is called the Post Da'wah. This concept refers to the facts that have happened lately. Da'wah which initially has values of the sacredity of values that upholds a truth of the state is then distorted by profane values. In fact, the new technology also supports pseudo reality in da'wah. Then, da'wah becomes a tool of manipulation in order to achieve economic benefits, bodily sexism, which is displayed through symbolic visualization. Da'wah is trapped in the world of imagery. Not only that propaganda, later became a political propaganda tool to seize power and maintain power. Interest takes precedence without regard to reason. These facts are referred to as Post Da'wah.
\end{abstract}

Keywords: Da'wah, Cyber, Culture, Strategy, Technology

\begin{abstract}
Abstrak
Perkembangan teknologi memberikan pengaruh besar di segala ranah kehidupan, termasuk dalam berdakwah. Para pendakwah menghadapi tantangan zaman di era cyber culture, di mana arus informasi dan perkembangan budaya terhubung dengan dunia yang serbadigital. Artikel ini membahas tentang hubungan antara dakwah dan cyber culture. Disertai apa saja tantangan yang mesti dihadapi para pendakwah, sekaligus bagaimana strategi yang pas untuk menyampaikan ajaran Islam di era kekinian. Pada bagian lain, dikemukakan pula apa yang disebut dengan Post Dakwah. Konsep ini mengacu pada fakta-fakta yang terjadi belakangan ini. Dakwah yang awalnya memiliki nilai-nilai sakralitas nilai yang menjunjung tinggi sebuah kebenaran keadaan kemudian terdistorsi oleh nilai-nilai profan. Bahkan, teknologi baru itu juga menyokong realitas semu pada dakwah. Kemudian, dakwah menjadi alat
\end{abstract}


manipulasi demi meraih keuntungan-keuntungan ekonomi, seksisme tubuh, yang ditampilkan melalui visualisasi simbolik. Dakwah terjebak dalam dunia citra. Tak hanya itu dakwah kemudian menjadi alat propaganda politik untuk merebut kekuasaan maupun mempertahankan kekuasaan. Kepentingan diutamakan tanpa mengindahkan nalar kebenaran. Fakta-fakta inilah yang disebut sebagai Post Dakwah.

Kata Kunci: Dakwah, Cyber, Budaya, Strategi, Teknologi

\section{PENDAHULUAN}

Perkembangan teknologi komunikasi dan informasi memberikan pengaruh terhadap aspek kehidupan masyarakat. Baik aspek ekonomi, politik, sosial dan budaya. Bahkan terhadap kehidupan sosial maupun privasi dari masyarakat tersebut. Di bidang pemerintahan, teknologi komunikasi dan informasi pun dioptimalkan demi memberikan pelayanan sosial di masyarakat Tak terkecuali adalah kehidupan dalam beragama. Jika diambil dalam kerangka lebih kecil, dalam upaya melakukan dakwah. Karena di era kekinian, model dakwah harus bisa beradaptasi². E-Dakwah atau dakwah menggunakan media digital adalah sebuah keniscayaan³. Tak ayal, banyak pendakwah maupun pondok pesantren yang sudah mengoptimalkan media sosialnya ${ }^{4}$.

Teknologi komunikasi dan informasi yang baru ini, orang menyebutnya dengan nama New Media5. Karena teknologi komunikasi ini telah menjadi pelengkap atau justru menggantikan teknologi lama. Atau dalam konsepsi paling moderat, teknologi baru ini justru melakukan kolaborasi dengan medium lama tersebut.

\footnotetext{
${ }^{1}$ Rio Febriannur Rachman. (2019). Optimalisasi Teknologi Komunikasi Informasi Command Center Bagi Efektifitas Tenaga Kesejahteraan Sosial Kecamatan. Dakwatuna: Jurnal Dakwah dan Komunikasi Islam, 5(2), 170-180.

${ }^{2}$ M. Darwis. (2016). Teologi Dakwah Dalam Kajian Paradigmatik. Dakwatuna: Jurnal Dakwah dan Komunikasi Islam, 2(1), 85-106.

3 Faiqotul Mala. (2017). "E-Dakwah": Tinjauan Awal Kontestasi Islam, Dakwah, Dan Internet. Dakwatuna: Jurnal Dakwah dan Komunikasi Islam, 3(1), 12-26.

${ }^{4}$ A. Farid. (2019). Optimalisasi Media Sosial Pesantren untuk Membendung Konten Negatif di Dunia Maya. Dakwatuna: Jurnal Dakwah dan Komunikasi Islam, 5(1), 30-37.

${ }^{5}$ Ron Rice mengatakan, "new media as communication technologies typically involving computer capabilities that allow and facilitate interctivity among users or between users an information". (Lievrouw et.al 2006:21-25)
} 
Perubahan-perubahan itu tidak hanya lingkup meleburnya batas-batas teritorial bangsa dan negara (Nation State). Perkembangan teknologi komunikasi dan informasi juga menghilangkan batas teritori sosial maupun individu. Baik individu dalam posisi subjektivitas beragama maupun individu dalam satu keluarga.

Tak hanya meleburnya konsep ruang, batasan-batasan waktu sekarang makin mengalami pengkaburan-pengkaburan. Tak seperti dulu lagi, identitas ruang dan identitas waktu memiliki dembarkasi yang sangat ketat. Sehingga batas-batas dari konteks ruang dan waktu kita bisa mengetahui dengan jelas.

Peleburan batas ruang dan waktu ini, orang menyebutnya sebagai cyberspace ${ }^{6}$. Atau ruang Maya. Ruang di mana tidak ada lagi batas ruang yang ada hanyalah persepsi dari manusia itu. Sebagaimana kehidupan manusia. Perkembangan ruang maya ini juga mengahasilkan budaya. Karena manusia yang berinteraksi di dalamnya juga membawa nilai-nilai maupun struktur sosial baru. Alih-alih manusia memanfaatkan struktur medium baru tersebut. Manusia justru makin terkendali dengan media baru?

Maka timbul hal baru dalam dunia maya tersebut. Tak persolan dalam penggunaan medium baru sebagai alat. Tapi hal pentinya lainnya, medium baru ini telah ikut andil dalam membentuk realitas baru. Menurut Burhan Bungin, realitas baru dalam dua nia maya ini disebut dengan konsep hiperealitas. ${ }^{8}$ Dari proses interaksi dan komunikasi dalam dunia maya ini juga menghasilkan budaya maya atau lebih dikenal dengan cyber culture. ${ }^{9}$ Ruang maya ini tepang

\footnotetext{
${ }^{6}$ Cyberspace berasal dari sebuah karya novel trilogi karya fiksi ilmiah milik William Gibson dengan sebuah Neuromancer (1984), Count Zero (1986) dan Mona Lisa Overdrive (1988). Kata ini ditunjukkan bagi tempat kata, hubungan manusia, data, kekayaan yang dijalankan melalui penggunakan teknologi komputer.(Bell, 2001:22).

7 Rio Febriannur Rachman, (2017). Menelaah riuh budaya masyarakat di dunia maya. Jurnal Studi Komunikasi, 1(2), 206-222.

${ }^{8}$ Bungin, 2006:160).Bungin, Burhan Bungin , Sosiologi Komunikasi;Teori, Paradigma dan Diskursus Teknologi di masyarakat, (Jakarta: Kencana Media Grup,2006),160

${ }^{9}$ Cyberculture berasal dari budaya yang muncul di dunia maya atau dunia siber. Budaya pada dasarnya merupakan nilai-nilai yang muncul dari proses interaksi antar individu,
} 
dengan budaya ini makin extensif penggunaanya. Apalagi bari para netizen. ${ }^{10}$ Atau warga baru dalam ruang internet. Penggunakan dunia maya ini makin massif. Banyak komunikasi menggunakan medium dunia maya tersebut.

Dalam ruang cyber culture inilah kemudian juga bergulat tentang isu agama. Taua lebih sepessifik dalam kajian ini tentang aktifitas dakwah. Baik dakwah secara lisan, tulsian maupun secara lembaga ${ }^{11}$. Ruang dunia maya ini pun penuh dengan nuansa dakwah. Karena dakwah sendiri merupakan kan tugas mulia bagi umat Islam dalam menyebarkan ajaran agama kepada manusia. Tugas yang mendapatkan perintah langsung dari Al-quran maupun Hadist. Bahkan ajaran dakwah juga mendapatkan panduan dalam Al-Quran dan risalah Nabi Muhammad. Bahkan dari pembacaan kedua sumber primer agama ini, beragam hukum disempatkan dalam aktifitas dakwah tersebut. Ada yang mengatakan Fardu Ain. Ada pula yang mengatakan hukumanya Fardu Kifayah ${ }^{12}$.

Maka tak heran, perkembangan agama Islam sejak Nabi Muhammad disebarkan melalui dakwah. Bahkan Islam yang menyebar di indonesia ini juga dilakukan melalui kegiatan dakwah. Sehingga Agama Islam banyak diterima di belahan dunia, bahkan para orientalis menyebut agama Islam ini sebagai agama dakwah. ${ }^{13}$ Meskipun ada pula sebagian kalangan di belahan dunia, di kawasan Barat misalnya, yang masih terkana Islamofobia karena asupan pesan melalui media massa yang sampai ke tempat itu belum proporsional ${ }^{14}$.

Apalagi di era pandemi Covid-19 ini, pemanfaatan teknologi komunikasi dan informasi atau lebih kongkritnya adalah internet mengalami signifikansi.

dalam konteks ini yaitu pengalaman individu dan atau antar individudalam menggunakan serta terkait dengan media (Nasrullah, 2014:4).

\footnotetext{
${ }^{10}$ Nunung Prajarto, "Netizen dan Infotainment: Studi Etnografi Virtual pada Akun Instagram @lambe_turah”, Jurnal komunikasi, Vol. No1, Juni 2018: 33-46

${ }^{11}$ Ropingi El Ishaq, Pengantar Ilmu Dakwah; Studi Konfrehensif Dakwah dari Teori ke praktek, (Malang: Madani,2016), 51

${ }^{12}$ El Ishaq, Pengantar Ilmu Dakwah, , 26

13 Tomas W. Arnold, Sejarah Dakwah Islam. Terj. Nawawi Rambe, (Jakarta : Widya 1981),1

${ }^{14}$ Rio Febriannur Rachman. (2018). Perspektif Karen Armstrong Tentang Islamofobia Di Media Barat. Dakwatuna: Jurnal Dakwah dan Komunikasi Islam, 4(2), 282-291.
} 
Dalam satu sisi mungkin pemanfaatan teknologi ini memberikan aspek positif terhadap persebaran informasi tak terkecuali adalah persebaran informasi tentang dakwah. Juga penggunakan media baru ini yang menjadi pertimbangan dalam aspek keselamatan kesehatan di era pandemi Covid-19. Intensitas penggunaan teknologi menjadi hal yang urgen. Bahkan masih aktvitas penggunaannya makin mendalam. Karena memang dengan medium teknologi ini pesan bisa tersampaikan.

Namun persoalannya, pemanfaatan teknologi internet atau teknologi Maya ini tidak serta-merta hanya menyampaikan sebuah pesan saja. Artinya Media baru hanya dijadikan sebagai alat penyampai pesan. Sehingga media baru ini penuh dengan pesan-pesan komunikasi.Ternyata, new media ini juga membawah pesan-pesanya sendiri. Justru tak hanya itu, media baru menjadi pentu pada pesan itu sendiri. Belum lagi pertarungan idiologi dalam medium baru tersebut. Karen medim ini berada dalam ruang sosial. Bukan pada ruang hampa. Maka tak jarang, medium baru juga menciptakan distorsi dari pesan tersebut. McLuhan tidak beralasan mengatakan bahwasanya medium-medium tidak hanya menyampaikan atau memuat isi pesan tetapi juga berdampak atau medium juga melakukan produksi pesan. Karena Medium is Massage. ${ }^{15}$

Hal ini senada dengan pandagan Jean Buldirad tentang simulasi. Berkat teknologi komunikasi ini, duni sedang berada dalam rungan tanpa rujukan. Tanda yang dirpresentasi tanpa menunjuk pada objeknya. Justru tanda telah menunjuk pada dirinya.

Akibatnya, banyak masyarakat tak mampu membedakan antara yang sebenarnya maupun dengan artifisial. Bahkan psedo tanda ini yang justru diyakini sebagai relaitas sebenarnya. Bahkan ruang tanda simulasi ini tak hanya menyentuh dalam dunia sosial. Tapi yang patu dikaji menyangkut aktifitas

15 Fazrian Noor Romadhon, Meme adalah Pesan: Analisis Akun Instagram Capres-Cawapres Fiktif @nurhadi_aldo dalam mengkritik Fenomena sosial, JIPP, vol. 4 no. 1, (15 november 2018), $15-20$ 
agama, yaitu dakwah. ${ }^{16}$ Ruang-ruang Maya sekarang di banyak dipenuhi oleh aktivitas dakwah terutama di platform platform media sosial. apakah terbentuk video, foto, maupun bentuk lainnya. Lebih-lebih dalam eara pandemi Civid-19 tersebut.

Namun masalahnya, apakah dakwah ah yang telah memanfaatkan teknologi ini sudah mencerminkan nilai-nilai dakwah yang sebenarnya? atau dakwah sudah mengalami terdistorsi oleh perkembangan medium teknologi tersebut? Karena jika merujuk pada teori semiotik Dakwah telah mengalami hipersemiotika ${ }^{17}$. Karena dakwah dalam mengalami pergeesaran-pergesaran. Tak hanya aspek teknologinya maupun subtansi dakwahnya mengalami bias bias. Makna dakwah sendiri mengalami lompatan lompatan pemaknaan dibanding konsepsi dakwah sebelumnya. Walaupun hal ini mungkin dianggap wajar akibat dialektika dakwah dengan news Media hingga menghasilkan cyber culture. Atau mengambil teorinya Derida tentang dekonstruksi, makna sebuah bahasa tidak pernah stabil. Ia selalu mengalami pengeseran maupun penundaan-penundaan. Karena bahasan terus dipengaruhi kontek ruang dan waktu. maka dalam konteks ini sangat relevan apabila dikonstruksikan dalam dakwah era cyberculture.

Dakwa sedang mengalami anomali-anomali daripada konsep dakwah sebelumnya. Seharusnya dakwah mengacu pada ajaran agama yaitu menyediakan kebahagiaan di dunia dan akhirat dakwah adalah bagian dari pencerahan bagian dari transformasi untuk kehidupan berkeadilan ${ }^{18}$.

Anomali-anomali tentang dakwah ini menjadi preseden baru terhadap keilmuan atau realita dakwah. Sejak awal penulis beranggapan ini sudah mengalami yang namanya pos dakwah atau dakwah yang telah melampaui

\footnotetext{
${ }^{16}$ Rulli Nasrullah dan Dudi Rustandi, Meme dan Islam: Simulakra Bahasa Agama di Media Sosial, Ilmu Dakwah: Academic Journal for Homiletic Studies, Vol. 10, No. 1 (Juni 2016) 113-128 ISSN 1693-0843

17 Wahyu Hanafi, HIPERSEMIOTIKA: Representasi Kedustaan Semiotika dalam Penafsiran alQur'an, QOF, Vol. 3, No. 1 (Januari 2019), 79-87

${ }^{18}$ El Ishaq, Pengantar Ilmu Dakwah, , 40
} 
meski tempos dakwah ini membutuhkan kajian-kajian lebih komprehensif baik secara keilmuan. Karena memang jika melihat dari realitas dakwah, Dakwah sudah melampaui dari dakwah tujuan dakwah itu sendiri.Maka dari itu, Dakwah cukup menarik bilamana dilihat wujud dakwah di dalam era cyberculture.

\section{PEMBAHASAN}

\section{Dakwah Kekinian}

Dakwah merupakan tugas mulia bagi umat Islam dalam menyampaikan ajaran agama kepada umat manusia lainnya. Tuntutan bagi umat islam untuk menjalankan dakwah telah tersurat dalam kitab suci Alquran maupun al-hadits. Dalam Al-Quran banyak ayat yang menjelaksan tentang seruan untuk melakukan dakwah. Semisal An-Nahl ayat 125. Artinya berbunyi:

"Serulah manusia kepada jalan tuhanmu dengan hikmah dan dan pelajaran yang baik dan bantahlah mereka dengan cara yang baik sesungguhnya tuhanmu dialah yang lebih mengetahui tentang siapa yang tersesat dari jalannya dan dialah yang lebih mengetahui orang-orang yang mendapatkan petunjuk".

Juga perintah dakwah terdapat dalam surat Al Imron ayat 104, Artinya berbunya:

"Dan hendaklah ada diantara kamu golongan umat yang menyeru kepada kebajikan, menyuruh pada yang ma'ruf dan mencegah dari yang mungkar. Merekalah orang-orang yang beruntung”.

Bahkan perintah dakwah ini juga ditegaskan lagi dan surat Al-Imron ayat 110. Artinya berbunyi:

"Kamu adalah umat yang terbaik yang dilahirkan pada umat manusia, menyuruh pada yang ma'ruf dan mencegah dari yang mungkar, dan beriman pada Allah. Sekiranya ahli kitab beriman, tentu lebih baik bagi mereka, diantara mereka ada yang beriman, dan kebanyakn mereka adalah orang-orang fasik". 
Maka dari itu, memiliki peranan penting dalam agama. Banyak cendekia Islam, baik para salafu ssholeh maupun intelektual masa kini, beragumentasi tentang ke wajiban menjalankan dakwah tersebut ${ }^{19}$. Ada pandangan menjalankan Dakwah sebagai fardu $\operatorname{Ain}^{20}$. Ada sebagian pula yang mengatakan melakukan aktifitas dakwah sebagai fardu Kifayah ${ }^{21}$.

Karna Dakwah itu sendiri bertujuan yang mulia. Menurut Ropingi, dalam bukung tentang Ilmu Dakwah. Tujuan dakwah ini bagi dua ${ }^{22}$. Yaitu tujuan jangka panjang dan tujuan jangka pendek. Untuk tujuan jangka panjang, Pertama, Dakwah ini bertujuan untuk mengaja beribadah pada Allah. Caranya dengan mengerjakan perintah-Nya dan menajuhi segala larangan-Nya. Kedua, meciptakan berkah bagi umat di dunia. Baik pada umat sendiri maupun umat lainnya. Ketiga, guna mendapatkan kebagiaan di dunia maupun di akhirat. Sedangkan tujuan Dakwah jangka pendeknya. Pertama, membina mental para muallaf yang baru masuk Islam. Sehingga iman mereka tetap kokoh dan tak keluar dari Isalm. Kedua, meningkatkan ketakwaan dan ke imanan umat Islam. Ketiga, mengajak pada selain umat Islam untuk menyakini ajaran Agama Islam.

Tak heran, mengingat pentingnya dakwah dalam beragama, kajian tentang dakwah pun mengalami signifikansi ${ }^{23}$. Banyak para tokoh dakwah atau cendekiawan Islam mendefinisikan tentang dakwah sendiri seperti Ali Mahfud $^{24}$. Ia mendefinisikan dakwah yaitu:

\footnotetext{
${ }^{19}$ Hamka, Prinsip dan Kebijaksanaan Dakwah Islam, (Jakarta: Pusta panjimas 1984), 20

${ }^{20}$ Fardu Ain adalah kawajiban yang disempatkan pada setiap umat Islam dakan berdakwah. Sehingga umat Islam yang tak menjalankan dakwah, mereka akan mendapatkan dosan. Pun sebaliknya mereka yang melakukan kegiatan dakwah akan mendapatkan pahala (Abdullah, 2018:75)

${ }^{21}$ Fardu Kifayah adalah kewajiban dakwah akan gugur bagi umat Islam, jika dalam sebuah wilayah ada satu orang yang telah melakukan dakwah. Jika hal demikian terjadi, maka orang yang tak melaksanakan dakwah tak berdosan. Sebaliknya, jika tak ada satu pun umat Islam tak melakukan Dakwah. Maka mereka semua harus menanggung dosa.

22 El Ishaq, Pengantar Ilmu Dakwah, , 40

23 Dengan makin pentingnya tentang dakwah, kajian-kajian tentang dakwah ini terus di kembangkan. Bahkan dakwah kini tak hanya dikaji dalam aspek dalam praktek menjalankan dakwah itu sendiri. Namun dakwah telah dikaji menjadi ilmu pengetahuan. Sehingga realitas dakwah ini dikaji dengan banyak aspek.

${ }^{24}$ Ali Mahfuzh, Hidayat Al Mursyidin (Al-Qahirah: Dar al-kitab,1952),17
} 
“ Mendorong manusia untuk melakukan kebaikan dan mengikuti petunjuk dan menyuruh mereka berbuat ma'ruf dan mencegah dari perbuatan mungkar agar mereka memperoleh kebahagiaan dunia dan akhirat".

Hal ini juga sebagaimana diungkapkan oleh Muhammad Arifin ${ }^{25}$ yang mengatakan dakwah memiliki arti ajakan baik ajakan itu dengan lisan, tulisan, dan tingkah laku. Baik ajakan itu dilakukan secara individual maupun kelompok sehingga dari upaya -upaya itu akan menciptakan pengertian perubahan sikap penghayatan pengamalan terhadap ajaran agama sebagai pesan yang disampaikan tanpa ada paksaan. Sejumlah pakar menyebutkan, salah satu metiode dakwah yang efektif serta efisien adalah dengan pendekatan interaktif berbasis kearifan lokal atau kultur masyarakat sasaran ${ }^{26}$.

Dari penjelasan di atas bisa diambil kesimpulan yang pertama adalah dakwah bisa dilakukan secara cara retorika, dengan tulisan atau bil kitabah dan perbuatan atau keteladanan dan aksi sosial yang kedua dalam melaksanakan dakwah akan melibatkan beberapa unsur dari dakwah itu yang pertama adalah dai atau orang yang berdakwah orang yang diajak atau sasaran dakwah dan pesan dakwah itu sendiri maupun media dakwah. Maka dari itu, merujuk pada unsur-unsur dakwah. Upaya melakukan dakwah tak bisa dilakukan secara serampangan. Bahkan dakwah ini harus dilakukan secara terencana dengan baik. Sehinga dakwah memiliki implikasi yang baik pada sasaran dakwah.

Misalnya para da'i atau juru dakwah dalam menyampaikan ajaran islam harus memiliki kompetensi-kompetensi tertentu dalam hal ini agama. Bahkan tidak hanya kompetensi agama tetapi kompetensi etika kemampuan keilmuan yang lain ini menjadi prasyarat harus dimiliki oleh seorang dai. Hari ini adalah untuk memberikan kesempurnaan dalam menyampaikan pesan ajaran agama. Karena tidak sembarang orang kemudian bisa menyampaikan ajaran agama tanpa didasari oleh ilmu pengetahuan tentang agama. Jika hal yang demikian

\footnotetext{
${ }^{25}$ M. Arifin, Psikologi Dakwah: suatu Pengantar Studi (Jakrata: Bumi Aksar,1991),6

${ }^{26}$ Rio Febriannur Rachman, (2018). Dakwah Intraktif Kultural Emha Ainun Nadjib. Jurnal Spektrum Komunikasi, 6(2), 1-9.
} 
terjadi maka akan terjadi yang namanya penyesatan agama karena orang yang tanpa tahu tentang agama menyampaikan pesan agama.

Maka Alquran telah mengajarkan kepada umat manusia bagaimana caracara menyampaikan agama yang baik dan benar banyak ayat yang menjelaskan tata cara menyampaikan agama atau berdakwah ini misalnya dengan cara bil hikmah mauidoh Hasanah dan berdebat dengan baik. Dengan cara ini, semangat untuk menyebarkan ajaran Islam yang ramah bisa mengemuka ${ }^{27}$.

Baginda nabi Muhammad SAW. dalam haditsnya berdakwah bisa dengan cara lisan dengan bil hal perbuatan maupun berdakwah dengan hati. Meski yang terakhir ini, kata Sabda nabi, selemah-lemah iman.

Secara historis kegiatan dakwah yang dilakukan nabi Muhammad SAW tidak hanya berbentuk dakwah secara lisan tapi yang banyak adalah dakwah secara uswah. Atau dakwah dengan contoh perbuatan yang baik. Bahkan pada era nabi juga menyelenggarakan dakwah dengan kegiatan-kegiatan aktivitas politik.

Maka kembali kepada dakwah banyak pengertian yang telah di definisikan oleh para pakar dakwah tapi yang jelas adalah dakwah mengajak manusia amal ma'ruf dan mencegah kemungkaran tujuannya adalah untuk mendapatkan kebahagiaan di dunia maupun akhirat.

\section{Cyber Culture}

Budaya budaya seiber merupakan budaya yang timbul dari fenomena dunia maya atau cyber culture hal ini ini dikarenakan proses interaksi antara cara individu sehingga menimbulkan pengalaman-pengalaman yang dimediasi oleh media media siber maksudnya. Bahkan tak hanya, interaksi dalam dunia maya ini juga akan menghasilkan nilai-nilai budaya ${ }^{28}$.

\footnotetext{
27 Faiqotul Mala. (2020). Mengkaji Tradisi Nabi Sebagai Paradigma Dakwah Yang Ramah. Dakwatuna: Jurnal Dakwah dan Komunikasi Islam, 6(01), 104-127.

${ }^{28}$ Rulli Nasrullah, Teori dan Riset Media Siber (Cybermedia) (Jakarta: Kencana, 2014), h.139
} 
Bagi Christina 2000 menyatakan uang cyber merupakan artefak budaya sehingga media siber yang awalnya hanya medium komunikasi yang sederhana bila dibandingkan dengan medium komunikasi tatap muka menghasilkan budaya-budaya yang memiliki ciri khas karena konstruksi oleh media ${ }^{29}$.

Maka dari itu dalam budaya cyber ini menghasilkan budaya-budaya yang cukup berbeda dengan budaya komunikasi media lainnya misalnya pemanfaatan simbul-simbul pemanfaatan emoticon dan pemanfaatan meme dan emotikon lainnya. Sehingga dalam cara cara berkomunikasi maupun memanfaatkan media cyber ini memiliki karakteristik yang berbeda dengan medium.

Berbagai macam bentuk medium interaksi hasil dari interaksi manusia dengan internet ini mulai dari newsgroup, chat, dan forum-forum chatting lainnya. Cyber culture merupakan budaya yang dimedia ole medium internet. Atau bisa dikatakan, cyber culter merupakan wujud perpaduan antara budaya personal komputer, telpon dan internet ${ }^{30}$. Sehingga penggabungan ini menghasilkan fungsi komunikasi yang berbeda dengan medium sebelumnya. Maka ini medium baru ini, menghasilkan juga fungsi perpaduan, fungsi hiburan fungsi pendidikan bahkan fungsi pemasaran.

Menurut Levy ${ }^{31}$, cyberculture is "that set of technologies (material and intellectual), practies, attitudes, modes of thought, and values that develop along with the growth of cyberspace."

Budaya cyber berupaka buda yang dihasilkkan dari interaksi antara manusian dengan internet. Dari interaksi ini menghasilkan bentuk interaksi yang khas bila

\footnotetext{
${ }^{29}$ Christine Hine, Virtual Etnhography, (London, Thousand Oaks, New Delhi: SAGE Publications, 2000), 27-38

30 Alice Tomic, Laura Lengel, and Crispin Thurlow, Computer Mediated Communication Social Interaction And The Internet, (California: Sage Publications, 2004), 30

${ }^{31}$ Pierre Levy, Cyberculture, Electronik Mediations, V. 4, Minneapolis, (Minn: London University of Minnesota Press, 2001), 31
} 
dengan interaksi dengan medium-medium lain. Meski masih dalam kerangka hubungan manusia dengan manusia ${ }^{32}$.

Dalam perkembangan budaya cyber ini telah berkembang sejak 19601990. Budaya cyber ini berkembangan kara didorong oleh teknologi komunikasi dan informasi berbasis internet. Atau dikenal dengan information, communication, and technology (ICT). ${ }^{33}$ ICT telah menjadi bagian penting dari perkembangan cyberculture. Maka dari itu, umat Isalm harus makin peduli dengan perkembnagan teknologi ini. Teknologi komunikasi ini tak hanya dijadikan alat saja. Tapi aspek teknologi dalam menentukan kehidupan juga perlu mendapatkan sorotan. Sehingga aspek negatif teknologi komunikasi ini juga terminimalisir.

\section{Refleksi Dialektika Dakwah dan New media}

Dakwah dengan misi penyebaran agama Islam ini ternyata tak berada di ruang kosong. Dakwah bergumul dengan entitas-entitas lainnya. Jika awalnya, dakwah harus bersingungan dengan kontek sosial, ekonomi dan budaya. Namun kini, dakwah harus bergumul juga dengan dunia maya atau komunikasi berbasis teknologi internet ${ }^{34}$.

Era cyberspace (siber) ini, para juru dakwah pun menafaatkan momentum tersebut. karena medium baru ini memberikan inmpak positif dalam kegiatan dakwah. Misalnya, jangkuan dakwah makin luas, efisen maupun efektif. Di era siber ini, semua pihak, termasuk pemerintah terbukti memanfaatkan media digital dalam melaksanakan kebijakan yang berhubungan langsung dengan masyarakat, termasuk di bidang ekonomi rakyat ${ }^{35}$. Banyak

\footnotetext{
32 Nayar K Pramod, The New Media and Cybercultures Anthology, (London, John Wiley and Sons Incorporated, 2010), 534

33 Ambar Sri Lestari, cyberculture membingkai dakwah kontemporer masyarakat modern, Zawiyah: Jurnal Pemikiran Islam, Vol. 3 No. 1, Juli 2017,1-19

${ }^{34}$ Abdul Ghofur. (2019). Dakwah Islam Di Era Milenial. Dakwatuna: Jurnal Dakwah dan Komunikasi Islam, 5(2), 136-149.

35 Rio Febriannur Rachman. (2019). Optimalisasi Media Digital Berbasis Kemaslahatan Umat dalam Program Pahlawan Ekonomi Surabaya. IQTISHODUNA: Jurnal Ekonomi Islam, 8, 273-292.
} 
pula kebijakan yang bersinggungan dengan industry kreatif berbasis digital ${ }^{36}$. Oleh sebab itu, pada da'i tidak boleh berpangku tangan, dalam artian harus pula memanfaatkan teknologi dalam menyambut era digital tersebut.

Para da'i pun banyak beranggapan, teknologi baru ini hanya sebagai alat penyambung lidah manusia saja. Sebagaimana alat-alat lainnya. Sehingga teknologi baru ini, tak memiliki dampak negatif. Nyatanya, selain dampak positif, new media ini juga memiliki dampak negatif. Alilih-alih kemudian alat komunikasi baru ini juga mengahasil budaya baru atau lebih di kenal dengan cyber culture.

Disinilah persingungan dakwah yang memiliki visi ilahi ini harus disokong dengan budaya maya. Bahkan kerapkali, budaya maya ini meminggirkan konsepsi dakwah yang benar. Dakwah pun mengalami pergesar-pergesaran ajaran-ajaran yang telah tersurat maupun tersirat dalam Al-Quran dan Al-Hadist. Bagi Jean Baudrillard tentang Simulacra and Simulations, budaya maya merupakan hasil hasilan dari realitas tak asli. Budaya yang tak memiliki rujukan objektif37. Namun mereka merujuk pada dirinya sendiri. Jika proses simulasi yang tak kenal henti ini. Maka akhirnya akan muncul namanya hiperrealitas. Citra sudah tak ada lagi bedanya dengan realitas. Bahkan banyak masyarakat mulai menggagap citra ini lebih objektif dari pada sebenarnya ${ }^{38}$. Awalnya, dunia hiperrealitas ini berada di ruang luar agama. Dua tanpa merujuk realitas bergumul dengan dunia sosial, budaya, ekonomi maupun politik. Namun perkembangan selanjutnya, hiperrelitas ini juga menyeret dalam ruang agama. Termasuk dalam berdakwah.

\footnotetext{
${ }^{36}$ Rio Febriannur Rachman. (2019). Pengembangan Industri Kreatif Berbasis Media Digital di Surabaya dalam Perspektif Islam. KOMUNITAS, 10(2), 157-176.

37http://profil.merdeka.com/ mancanegara/j/jean-baudrillard diunduh pada 21 Juni 2020.

${ }^{38}$ Mark Poster. "Introduction”. Mark Poster (ed.). Jean Baudrillard: Selected Writings. Diunduh dari http://www.humanities.uci.edu/mposter/books/Baudrillard,\%20Jean\%20- \%20Selected\%20 Writings.ok.pdf pada 22 Juni 2020.
} 
Jika hal itu terjadi, kegiatan agama terselah terseret dalam dunia citra, konsumerisme dan komuditas ${ }^{39}$. Disaat itulah, agama mulai terjebak dalam wilayah artifisil, buatan maupun ke dangkalan. Dalam hal ini kegiatan dakwah telah menjahi nilai-nilai hakikinya. Dakwah makin jauh dari konsepsi maupun tujuannya. Yaitu dakwah yang hanya ditujukan mendekatkan pada yang kholik. Dakwah dilakukan secara ikhlas. Bahkan dakwah preferensinya hanya diniatkan untuk mencari ridho dan pahala dari sang pencipta. Pergumulan dengan dakwah dengan cyber culture ini, penulis sebut dengan namanya "Post Dakwah".

Mungkin konsep ini, banyak beranggapan masih cukup prematur. Tapi penulis melihat dakwah tak lagi bisa dikonsepsikan atau telah melampui konsep dakwah-dawak terdahulu. Makna dakwah telah mengalami pergegeseran. Dakwah makin menjauhi dari fodasi agama. Hal bisa diliaht dari realitas dawah sebagaimana berikut:

1. Peminggiran nalar dakwah uswah

Pergulatan aktivitas dakwah dengan konteks teknologi informasi juga mengalami pergeseran-pergeseran. Dimana pada era dulu aktivitas dakwah terjalin erat bagaikan mata koin uang antara kegiatan dakwah verbal dengan dakwah uswah dakwah uswah. Namun saat ini adalah pergulatan teknologi dan dakwah ini telah memikirkan wacana dakwah uswah ini.

Saat ini para dai berlomba-lomba bagaimana mentransformasi pesan melalui teknologi informasi dan komunikasi berupa internet pesan ini disampaikan secara masif kepada masyarakat bahkan kerap kali terjadi sebuah gelembung informasi.

Informasi yang berkelindan di dunia maya ini kemudian tidak bisa terkontrol sehingga menciptakan informasi yang informasi yang absurd karena terjadi lompatan-lompatan informasi tersebut.

\footnotetext{
39 Farida Rachmawati, Rethinking Uswah Hasanah: Etika Dakwah dalam Bingkai Hiperrealitas, Jurnal Ilmu Dakwah, Vol. 35, No.2, Juli - Desember 2015 ISSN 1693-8054, 307-333.
} 
Kita bisa melihat bagaimana ruang-ruang media sosial baik itu berplatform YouTube Facebook Instagram maupun web dipenuhi dengan aktivitas dakwah apalagi di era pandemi covid 19 ini civitas kegiatan dakwah melalui teknologi komunikasi semakin masif. Para dai memanfaatkan teknologi ini dalam menyampaikan pesan-pesan dakwahnya. Persoalannya dalam pemanfaatan teknologi ini kerapkali hanya dimobilisasi dengan pesan-pesan pesan-pesan verbal saja tanpa disokong oleh kesalehan kesalehan perilaku untuk menjadi role model dalam kehidupan beragama.

Akibatnya banyak umat Islam mengkonsumsi pesan dakwah melalui medium internet ini hanya memahami dari aspek luarnya saja dalam beragama. Mereka tidak mengetahui secara benar dan pasti otorisasi dalam penyampaian agama. Apalagi kita tahu di media media sosial misalnya pesan-pesan agama sendiri juga ditunggangi oleh eh kepentingan-kepentingan diluar agama itu sendir. Bahkan kerap kali sangat lebar disparitas antara dakwah secara verbalitas isi dakwah secara verbal dengan uswah dari penyampai dakwah itu. Ini yang menjadi problem bagi dakwah itu sendiri karena juga akan mengeringkan kan paham keagamaan umat Islam sendiri. Karena mereka tidak memiliki model perilaku yang absah dalam beragama yang dicontohkan oleh para cendekiawan cendekiawan muslim tersendiri.

2. Komodifikasi dakwah

Bahkan tidak hanya pergeseran atau peminggiran dakwah khutbah daripada dakwah dakwah pemanfaatan verbal ternyata kegiatan dakwah yang berkelindan di media sosial ini juga juga mengalami distorsi pesan dakwah itu sendiri. Dakwah yang memiliki tugas mulia dalam menyampaikan agama Islam kepada umat manusia yang telah ditugaskan oleh Allah dan tugas ini sudah tertera dengan jelas di Al-Quran maupun Hadist merupakan tugas mulia bagi umat manusia utamanya bagi umat Islam.

Karena tugas ini akan mendapatkan pahala bagi orang yang menyebarkan agama pun demikian bagi orang yang belajar agama juga akan 
mendapatkan pahala bahkan janjinya Allah di dalam Alquran orang yang menyebarkan agama ini akan mendapatkan atau mendapatkan kebahagiaan di dunia dan akhirat maka di akhirat nanti secara spesifik akan mendapatkan atau ditempatkan di dalam surga.

Maka dari itu dalam menyampaikan dakwah seharusnya dai harus mengedepankan nilai-nilai agama, mengedepankan wuj dia sebagai khalifah fil ardhi yang mendapatkan amanah dari Allah untuk menyebarkan agama Islam. Tapi persoalannya adalah di era cyber culture ini pergulatan dakwah dengan teknologi komunikasi dan informasi ini sudah tidak murni seperti itu lagi dakwah itulah telah disisipi dengan kepentingan-kepentingan ekonomi. Dakwah tidak murni lagi memenuhi tuntutan agama dalam menyebarkan agama Islam alihalih seperti itu dominasi kepentingan ekonomi menjadi di penentu arus utamanya.

Maka tak heran kalau kita lihat kegiatan-kegiatan dakwah melalui media sosial misalnya agregasi pesan dakwahnya mungkin cuman sekian persen tapi motif ekonomi dalam menyampaikan dakwah itu menjadi lebih besar motivasi melakukan dakwah tidak lagi didasari oleh tugas agama dalam menyebarkan agama Islam tapi motif ekonomi yang menjadi panglimanya. Al Ghazali dalam kitab ihya Ulumuddin ${ }^{40}$ sudah menjelaskan menyebarkan agama merupakan kewajiban bagi intelektual-intelektual Islam atau dalam hal ini para dai yang telah memiliki kompetensi agama dalam menyampaikan pesan agama Islam karena tugas menyampaikan agama ini ini nanti akan di dibalas dengan atau oleh Allah subhanahu wa ta'ala. Tapi ironisnya janji Allah bagi para intelektual Islam para dai dengan pahala berupa surga hanya di ukur dengan kepentingankepentingan materialisme belakang padahal materialis ma ini hanya bersifat profat ya cukup dunia saja.

40 Al Ghazali, Amar ma'ruf nahi mungkar. Terj. Imran Abu Bakar Abu Amar, (Jakarta: pustaka Amani 1984).30 
Di sinilah kemudian kalau bahasa penulis adalah wujud dari komodifikasi dakwah kepentingan-kepentingan ekonomi menyisipi pesan dakwah. Alih alih tujuan ekonomi lebih penting dari tujuan dakwah sendiri karena akan berdakwah jika berimpact terhadap ekonomi. Penelitian-penelitian tentang komunikasi dakwah ini sudah banyak para peneliti melihat pergeseranpergeseran tentang dakwah itu sendiri. Dakwah yang memiliki tugas mulia menyebarkan agama Islam telah ditunggangi oleh kepentingan-kepentingan dunia dan hal ini sangat bertentangan sekali dalam ayat-ayat Alquran. Allah dalam FirmanNya artinya adalah "janganlah kamu menjual ayat-ayat al-quran dengan harga murah". Seperti saat ini menjual kehidupan abadi kebahagiaan yang abadi dengan materi cuman sebentar padahal kehidupan akhirat itu lebih kekal.

\section{Perfovitas dakwah}

Selain komodifikasi agama komodifikasi dakwah yang menjadi fenomena baru di dalam dakwah berkelindan dengan media sosial ini adalah wujud baru kegiatan-kegiatan dakwah yang dilakukan kan oleh para dai-dai yang hanya menampilkan performavitas tubuhnya. misal yang lagi trend kekinian adalah tentang kelompok hijrah, hijaber dan komunitas-komunitas di ruang virtual atau bisa disebut dengan cyber community berbalut dengan simbol-simbol agama. Simbol agama menjadi sangat menonjol dalam ruangruang ini bahkan yang lebih ngerti adalah simbol simbol ini kemudian diberi narasi-narasi yang hyperrealis. Maka dari itu, banyak sekali umat islam terjebak pada kesalehan kesalehan tubuh bukan pada kesalehan kesadahan substantif orang dikatakan beragama ketika memiliki kesalahan-kesalahan tubuh ini.

Mungkin bentuk simbolisasi agama ini didukung oleh teknologi komunikasi dan informasi karena di era new media atau cyber culture ini pemanfaatan kode-kode visual ini lebih baik bahkan menjadi trend dalam komunikasi visual.Kesalehan kesalehan tubuh menjadi cukup dominan daripada 
kesalehan kesalehan spiritual kemudian yang ditampilkan adalah bentukbentuk kesalehan kesalehan itu.

Banyak penelitian penelitian tentang yang per formalitas dalam agama ini bahkan ini disajikan di dalam ruang-ruang komunitas komunitas virtual. Misal kelompok hijaber kelompok hijrah dan kelompok-kelompok komunitaskomunitas Islam baru mereka banyak hanya menampilkan sisi-sisi penyajian penyajian agama dalam konteks penampilan tuh bersahaja. Tanpa apa di barengi kedalaman kedalaman dalam pemahaman agama yang sering terjadi adalah tokoh-tokoh agamanya pun hanya pandai mempermainkan performa Vita subuhnya didukung oleh creator content agama.

Yang terjadi kemudian ukuran-ukuran tokoh agama itu dengan penampilan penampilan tubuh yang kemudian didukung oleh banyaknya like banyaknya follower dan pesan-pesan yang menghipnotis. Bukan pesan-pesan agama yang sebagaimana dari tujuan dakwah itu sendiri yang sudah terang benderang di dalam Alquran maupun hadis.

Ironisnya lagi performativitas ini juga ternyata banyak dimotivasi bukan atau ikhlas dalam menyebarkan pesan-pesan agama tetapi hanya memproduksi nilai-nilai kepentingan ekonomi maka tak heran kemudian kelompok-kelompok komunitas-komunitas banyak bermunculan simbol-simbol agama itu ternyata di dalamnya jadi ajang menjual produk jadi ajang untuk kapitalisasi ekonomi.

\section{Pergeseran otoritatif agama}

Perkembangan teknologi informasi yang dimanfaatkan sebagai medium dakwah ternyata juga tidak hanya memberikan aspek efektifitas dakwah dalam menyebarkan pesan-pesan Islam. memang betul teknologi selama ini cukup berperan memberikan layanan atau subtitusi medium dakwah.

Karena dengan teknologi ini dakwah semakin tersebar, jangkauannya semakin luas bahkan dengan teknologi ini kemudian menghilangkan sekat-sekat waktu dan ruang terutama dengan medium saiber ini. 
Bahkan di tengah pandemi covid-19 atau Corona ini teknologi semakin dibutuhkan semua aras kehidupan sosial menggunakan platform teknologi karena mereka kingin tetap melakukan aktivitas namun tanpa terjangkit oleh eh atau terpapar covid 19. Maka pilihannya adalah memanfaatkan teknologi informasi dalam hal ini di era sekarang adalah internet yang wujudnya berbagai macam atau dikasih atau plafon yang menyediakan sarana komunikasi. Termasuk dakwah Islam dakwah Islam mengambil peran ini cukup strategis sehingga banyak ruang ruang di dalam teknologi baru ini menyajikan tentang dakwah Islam atau pesan-pesan Islam. Bahkan akibat pandemi Corona ini semua aktivitas kegiatan keberagamaan yaitu utamanya dakwah menggunakan platform media siber ini.

Tak hanya keagamaan keagamaan yang yang berada di masyarakat bahkan keagamaan yang digelar di pondok pondok pesantren pun juga melakukan komunikasi atau pengajian secara daring. Hubungan santri dengan kyai banyak dilakukan secara daring tidak lagi pengajian pengajian santri dengan kyai didominasi dengan melakukan tatap muka tapi sudah memanfaatkan aplikasi aplikasi yang berbasis digital.

Mungkin sebagaimana yang telah dijelaskan di atas memiliki sisi positif tapi ternyata teknologi ini juga memiliki sisi negatifnya yaitu sebagaimana teorinya McLuhan medium is message message ternyata media juga membawa tidak hanya membawa pesan dengan pandangan-pandangan positivistik. Seperti kata Berger juga melakukan konstruksi sosial bahkan sekarang medium semakin menjadi penentu dalam kehidupan transformasi sosial. Masyarakat semakin tergantung dengan teknologi informasi ini termasuk dalam dakwah Islam di tengah belantara informasi tentang Islam pesan-pesan dakwah masyarakat sudah tidak lagi memiliki kedekatan dengan otoritas keagamaan mungkin dalam konteks Indonesia adalah kyai intelektual Islam atau orang yang memiliki kapasitas keilmuan agama. 
Justru banyak masyarakat kemudian memanfaatkan kan teknologi dalam belajar tentang agama meski konten-konten yang tanpa memiliki kejelasan otentisitas ajaran agamanya. Apalagi di era pos truth ${ }^{41}$ ini semua atau banyak informasi-informasi yang kemudian melampaui kebenaran. Di sinilah bahayanya pergeseran otoritasi keagamaan dari tokoh-tokoh intelektual Islam menuju teknologi komunikasi bahkan kalau kita lihat banyak orang-orang yang mengaku paham agama orang-orang yang yang memahami agama secara tekstual simbolis hanya belajar dari media ini tanpa melihat referensi kebenaran dari ajaran agama agama itu.

Yang paling ngeri juga kemudian pemahaman pemahaman agama yang tanpa memiliki sanad yang mutawatir atau sangat yang nyambung dari guru ke guru hingga kepada Rasulullah. Di sinilah akan terjadi pelung terdistorsinya pemahaman agama sehingga tidak heran kemudian kita lihat banyak kegiatankegiatan agama yang memunculkan hanya proses simbolik memunculkan aktivitas-aktivitas agama dengan kesalehan keshalihan simbolik soalnya berjuba kemudian pakai sorban bahkan ini ditampilkan dalam medium medium itu. Sehingga masyarakat banyak memahami agama Islam hanya di tinjauan tah kan oleh proses Islam yang simbolik itu padahal Islam tidak hanya itu yang paling lebih penting semuanya selain kesalahan-kesalahan virtual kesalehan-keselahan visual tetapi juga yang penting adalah keselahan-keselahan batiniah untuk mendekatkan kepada sang khalik.

5. Hiperrealitas dakwah

Di tengah cyber culture telah menjadi tantangan baru terutama tentang dakwah ini. Karena dakwah sudah tidak dilakukan secara konvensional kalau bahasanya pilihan tapi sekarang yang banyak sudah dilakukan melalui medium teknologi. Meski masih ada dakwah yang di lakukan secara tradisional

\footnotetext{
${ }^{41}$ Moh Muhtador Studi Kritis atas tranmisi dan otoritas Keagamaan di media sosial, Fikrah : Jurnal Imu Aqidah dan Studi Keagamaan, Vol. 06, No. 22018 ISSN 2354-6147-9649,323-340
} 
melakukan tatap muka melakukan dialog pertemuan diskusi dan lain sebagainya.

Ruang-ruang maya ini semakin intensif disaat covit-19 ini aktivitas keagamaan sudah dilakukan secara daring.sajian sajian pesan Islam disajikan melalui platform media sosial pertimbangannya tidak hanya ngomong efektivitas perluasan bersebaran tapi juga tentang menjaga kesehatan persebaran virus Corona.

Bahkan perkembangan dari dunia realitas menuju dunia maya ini sekarang semakin dalam. Banyak efek-efek dari teknologi negatif ini berdampak pada dakwah tersendiri. Mulai dari dakwah yang sudah tidak murni lagi dan yang lebih mengerikan adalah dakwah berada dalam proses belantara informasi maka kondisinya bisa disebut dengan arena chaos. Sehingga banyak umat Islam tidak memahami tentang kebenaran pesan Islam yang ada di dunia digital. Apalagi juga dakwah juga disusupi kepentingan-kepentingan untuk tujuan perebutan kekuasaan maupun melanggengkan kekuasaan. Distorsi-distorsi inilah dakwah dalam konteks realitas sudah mengalami namanya hiperrealitas dakwah yang artinya bagai pesan agama pesan untuk keselamatan ternyata telah melampaui pesan-pesan tersebut yang ditopang oleh teknologi informasi. Dakwah telah terjebak pada yang profan dari pada yang abadi.

6. Imagologi dakwah

Dakwah di tengah perkembangan teknologi informasi dan komunikasi juga mengalami gelembung pemaknaan arus dakwah. Kalau dulu dakwah memiliki tujuan-tujuan mulia sebagaimana ditegaskan di dalam Alquran yaitu menyampaikan pesan-pesan ilahi dengan berharap pahala dari Allah subhanahu wa ta'ala. Namun di dalam cyber culture ini dakwah mengalami lompatan lompatan bahkan acapkali terjadi destruksi pemahaman dakwah. kalau orang mungkin lebih menyebutkan ini dengan sebutan imagologi. Imagologi menurut yasraf Amir Piliang berasal dari kata idea dan logos. Image adalah citra tampilan permukaan dan artifisial. Sementara logos merupakan ilmu. Era sekarang orang 
berlomba-lomba ingin mencitrakan tentang sebuah simbol kalau dalam terms saat ini adalah simbol dakwah. Bahkan pencitraan-pencitraan ini kerapkali mendistorsi dari dakwah itu sendiri. Bahkan yang lebih parah terjadinya pencitraan ini berkolaborasi berkelindan ria dengan teknologi informasi maka terjadilah kemudian pengaburan realitas sehingga yang muncul adalah masifikasi realitas Citra.

Apalagi kemudian ditopang oleh algoritma media digital sehingga kedalaman Citra ini makin penjarah diary realitas. Ironisnya hal ini yang terus diproduksi dan diproduksi sehingga menyebabkan menganggap realitas sebenarnya. Bahkan dengan platform digital itu kita ini tidak lagi hanya berada di ruang publik tapi berada di ruang privat di lingkungan keluarga bahkan saat kita sendirian diterpa oleh dunia Citra. Dunia yang tanpa memiliki katakan dengan realitas ini kemudian dijadikan konsumsi yang berulang-ulang pun menjadi sebuah kenyataan baru yang diyakini bahkan melebihi dari realitas yang ada.

Maka tidak heran kalau kemudian munculnya paham paham agama baru paham paham yang mengesampingkan nilai-nilai toleransi-toleransi, mengesampingkan nilai-nilai iman dalam beragama. Agama menjadi agama pemarah bahkan sekarang yang lagi ngetren muncullah yang namanya populasi-populasi semua agama-agama kemudian menjadi hanya penampakan pencitraan pencitraan yang ditopang oleh pentingan kepentingan apakah kepentingan ekonomi maupun kepentingan politik.

7. Dakwah alat propaganda politik

Anomali-anomali tentang dakwah ini juga mengalami distorsi di dalam bidang politik. Meski ada adigium dalam politik, politik merupakan sebuah pertarungan simbol yang tidak bisa lepas dari kepentingan. Tapi seharusnya politik itu menyajikan kepentingan-kepentingan yang berorientasi kemaslahatan bagi umat manusia. Memang sejak zaman zaman nabi dakwah itu tidak hanya disajikan dalam bentuk sebuah artikulasi dakwah bil lisan tetapi juga 
nabi mencontohkan kita berdakwah secara politik kalau kita lihat secara historis nabi mengemas dakwahnya perpindahan nabi dari Mekah ke Madinah kemudian membentuk komunitas kota di Madinah disitu sudah terjadi sebuah proses pemerintahan atau kalau sekarang lebih terkenal dengan konsep civil society.

Nabi telah mengajarkan bagaimana konsep-konsep pemerintahan yang baik dalam kontek pada waktu itu bahkan pemerintahan di Madinah ketika nabi pun kembali ke Mekah ketika nabi berhasil menaklukkan Mekkah itu kemudian dibangun pemerintahan yang berdasarkan prinsip-prinsip agama walaupun demikian nabi tetap rujukannya dalam membangun manusia dan membangun masyarakat berpedoman kepada al-quran dan hadis Alquran karena nabi-nabi mendapatkan bimbingan langsung dari Allah subhanahu wa ta'ala.

Namun berbeda dengan sekarang walaupun banyak gerakan-gerakan dakwah yang bernada bergerak di bidang politik. Seharusnya kegiatan politik dan bernafaskan Islam. Bukan sebalinya, gerakan gerakan politik Islam yang tidak mendasarkan pada ajaran Islam. Misalnya misalnya hasil pengungkapan kepolisian terhadap salah satu group cyber army. Dalam cyber comunity ini gerakan-gerakan politik yang dibungkus dengan gerakan-gerakan agama di mana memanfaatkan teknologi media teknologi komunikasi untuk melakukan propaganda politik untuk menjatuhkan pemerintahan yang sah dengan tameng simbol-simbol agama.

Bahkan agama kemudian menjadi alat propaganda politik untuk merongrong sebuah kekuasaan, merongrong sebuah tatanan sehingga ini diproduksi secara massal yang didukung oleh instrumen media terutama faktorfaktor media digital. Sehingga isu politik yang diproduksi secara massal ini akan menjadi realitas baru akhirnya. Bahkan corak politik yang dibungkus dengan simbol-simbol agama ini tidak hanya menyajikan pesan-pesan yang bernada agama tetapi kemudian mengabaikan kebenaran dari pesan itu. Pesan-pesan agama atau pesan-pesan politik hanya mengeksploitasi nilai-nilai emosional 
agama atau sisi psikologis umat beragama tanpa mengindahkan kaidah-kaidah kebenaran rasionalitas atau fatsun-fatsun kebenaran yang ada diobok-obok adalah masalah-masalah yang bersentuhan dengan sensitivitas keyakinan. Sehingga banyak masyarakat terjebak oleh perbutan aganda politik. Dakwah sekarang bukan lagi untuk melakukan transformasi sosial justru agama kemudian dijadikan sebagai alat untuk melanggengkan sebuah tatanan baru tatanan populisme agama yang bertentangan dengan kaidah-kaidah agama di masyarakat.

\section{PENUTUP}

Melihat pembahasan di atas, strategi dakwah sangat berpengaruh sekali dalam era cyber culture tersebut karena dakwah harus bergulat di tengah nilainilai budaya. Bahkan acap dakwah tidak hanya memanfaatkan teknologi. Tapi sekali lagi dakwah pun dipengaruhi oleh teknologi ini. Sehingga dakwah yang awalnya memiliki nilai-nilai sakralitas nilai yang menjunjung tinggi sebuah kebenaran keadaan kemudian terdistorsi oleh nilai-nilai profan. Bahkan hal yang sangat miris medium teknologi baru itu juga menyokong realitas semu pada dakwah.

Ini terbukti dakwah tidak hanya berorientasi sebagaimana telah ditetapkan Allah dalam Alquran maupun risalah nabi Muhammad, dakwah bertujuan menciptakan manusia-manusia yang baik memberikan peringatan memberikan kabar gembira akan kesejahteraan di dunia dan akhirat tapi malah dakwah telah meminggirkan tujuan-tujuan baik itu itu dengan tujuan-tujuan kan materi. Bahkan yang lebih parah dakwah kemudian menjadi alat manipulasi terhadap fenomena dakwah demi meraih keuntungan-keuntungan ekonomi, seksisme tubuh, ditampilkan visualisasi simbolik. Hingga realitas tanpa makna subtansi. Dakwah terjebak dalam dunia citra. Tak hanya itu dakwah kemudian menjadi alat propaganda politik untuk merebut kekuasaan maupun 
mempertahankan kekuasaan. Kepentingan diutamakan tanpa mengindahkan nalar kebenaran. Fakta-fakta inilah kami menyebutnya sebagai Post Dakwah.

\section{REFERENSI}

Abdullah. 2018. Ilmu dakwah dalam kajian ontologi epistemologi aksiologi dan aplikasi dakwah. Depok: PT raja grafindo persada.

Akmalia, Wahyudi. Bukan sekedar panggung (buzzers) : media sosial dan transformasi politik. Ma'arif institute titik 2 Ma'arif vol.1 (Juni 2018).

Al Ghazali. 1984. Amar ma'ruf nahi mungkar. Terjemah titik Imran abu bakar abu Amar.. Jakarta: pustaka Amani.

Arifin, Ferdi. Mobile YouTube dan komodifikasi konten dakwah. Al balagh: jurnal dakwah wah dan komunikasi vol. 4, no.1, (1 Januari-Juni 2019).

Arifin, M. 1991. Psikologi Dakwah: suatu Pengantar Studi. Jakrata: Bumi Aksar.

Bungin. Burhan.220.Sosiologi Komunikasi;Teori, Paradigma dan Diskursus Teknologi di masyarakat. Jakarta: Kencana Media Grup.

Darwis, M. (2016). Teologi Dakwah Dalam Kajian Paradigmatik. Dakwatuna: Jurnal Dakwah dan Komunikasi Islam, 2(1), 85-106.

El Ishaq, Ropingi. 2016.Pengantar Ilmu Dakwah; Studi Konfrehensif Dakwah dari Teori ke praktek. Malang : Madani.

Farid, A. (2019). Optimalisasi Media Sosial Pesantren untuk Membendung Konten Negatif di Dunia Maya. Dakwatuna: Jurnal Dakwah dan Komunikasi Islam, 5(1), 30-37.

Ghofur, A. (2019). Dakwah Islam Di Era Milenial. Dakwatuna: Jurnal Dakwah dan Komunikasi Islam, 5(2), 136-149.

Hamka.1984. Prinsip dan Kebijaksanaan Dakwah Islam.Jakarta: Pusta Panjimas. Hine, Christine. 2000. Virtual Etnhography. London, Thousand Oaks, New Delhi: SAGE Publications. 
Hanfi, Wahyu Hanafi, Hipersemiotika: Representasi Kedustaan Semiotika dalam Penafsiran al-Qur'an, QOF, Vol. 3, No. 1 (Januari 2019), 79-87

http://profil.merdeka.com/ mancanegara/j/jean-baudrillard diunduh pada 21 Juni 2020.

Lestari, Ambar asri. Cyber culture membingkai dakwah kontemporer masyarakat modern. Zawiyah: jurnal pemikiran Islam. vol. 3, No.1 (Juli 2017)

Levy, Pierre. 2001. Cyberculture, Electronik Mediations, V. 4, Minneapolis. Minn: London University of Minnesota Press.

Mahfuzh, Ali. 1952. Hidayat Al Mursyidin. Al-Qahirah: Dar al-kitab.

Mala, F. (2017). “E-Dakwah”: Tinjauan Awal Kontestasi Islam, Dakwah, Dan Internet. Dakwatuna: Jurnal Dakwah dan Komunikasi Islam, 3(1), 12-26.

Mala, F. (2020). Mengkaji Tradisi Nabi Sebagai Paradigma Dakwah Yang Ramah. Dakwatuna: Jurnal Dakwah dan Komunikasi Islam, 6(01), 104-127.

Mark Poster. “Introduction”. Mark Poster (ed.). Jean Baudrillard: Selected Writings.

Diunduh

dari http://www.humanities.uci.edu/mposter/books/Baudrillard,\%20Jean\%20\%20Selected\%20 Writings.ok.pdf pada 22 Juni 2020.

Mutdor, Moh. Studi Kritis atas tranmisi dan otoritas Keagamaan di media sosial, Fikrah : Jurnal Imu Aqidah dan Studi Keagamaan, Vol. 06, No. 22018 ISSN 2354-6147-9649,323-340

Nasrullah, Rulli. 2014. Teori dan Riset Media Siber (Cybermedia).Jakarta: Kencana.

Nasrulloh, Ruli dkk. Meme dan Islam: simulacra bahasa agama di media sosial. Ilmu dakwah: academic journal for homelitic studies. vol. 10, No. 1 (Juni 2016) 113-128 ISSN 1693-308

Prajarto, Nunung Prajarto. "Netizen dan Infotainment: Studi Etnografi Virtual pada Akun Instagram @lambe_turah”. Jurnal komunikasi, Vol. No1, Juni 2018: $33-46$ 
Pramod, Nayar K. 2010. The New Media and Cybercultures Anthology, (London, John Wiley and Sons Incorporated.

Rachman, R. F. (2017). Menelaah riuh budaya masyarakat di dunia maya. Jurnal Studi Komunikasi, 1(2), 206-222.

Rachman, R. F. (2018). Dakwah Interaktif Kultural Emha Ainun Nadjib. Jurnal Spektrum Komunikasi, 6(2), 1-9.

Rachman, R. F. (2019). Optimalisasi Media Digital Berbasis Kemaslahatan Umat dalam Program Pahlawan Ekonomi Surabaya. IQTISHODUNA: Jurnal Ekonomi Islam, 8, 273-292.

Rachman, R. F. (2019). Optimalisasi Teknologi Komunikasi Informasi Command Center Bagi Efektifitas Tenaga Kesejahteraan Sosial Kecamatan. Dakwatuna: Jurnal Dakwah dan Komunikasi Islam, 5(2), 170180.

Rachman, R. F. (2019). Pengembangan Industri Kreatif Berbasis Media Digital di Surabaya dalam Perspektif Islam. KOMUNITAS, 10(2), 157-176.

Rachman, R.F. (2018). Perspektif Karen Armstrong Tentang Islamofobia Di Media Barat. Dakwatuna: Jurnal Dakwah dan Komunikasi Islam, 4(2), 282291.

Rachmawati, Farida. Rethinking Uswah Hasanah: Etika Dakwah dalam Bingkai Hiperrealitas, Jurnal Ilmu Dakwah, Vol. 35, No.2, Juli - Desember 2015 ISSN 1693-8054, 307-333.

Romadhon, Fazrian Noor. Meme adalah Pesan: Analisis Akun Instagram CapresCawapres Fiktif @nurhadi_aldo dalam mengkritik Fenomena sosial, JIPP, vol. 4 no. 1 , (15 november 2018), 15-20

Rustandi, Rulli Nasrullah dan Dudi. Meme dan Islam: Simulakra Bahasa Agama di Media Sosial, Ilmu Dakwah: Academic Journal for Homiletic Studies, Vol. 10, No. 1 (Juni 2016) 113-128 ISSN 1693-0843 
Harry Purwanto, Achmad Arifulin Nuha

Sumrahadi, Abdullah: harus teknologi global: tantangan eksistensi agama dalam ruang sosial kapitalisme data. Ma'arif institute: Ma'arif vol. 1 (Juni 2018)

Tomic, Alice dkk. 2004. Computer Mediated Communication Social Interaction And The Internet. California: Sage Publications..

W. Arnold, Tomas.1981. Sejarah Dakwah Islam. Terj. Nawawi Ramb. Jakarta : Widya. 